\title{
Glucocorticoid-induced insulin resistance in skeletal muscles: defects in insulin signalling and the effects of a selective glycogen synthase kinase-3 inhibitor
}

Received: 14 December 2004 / Accepted: 16 May 2005 / Published online: 3 August 2005

C) Springer-Verlag 2005

\begin{abstract}
Aims/hypothesis: Treatment with glucocorticoids, especially at high doses, induces insulin resistance. The aims of the present study were to identify the potential defects in insulin signalling that contribute to dexamethasone-induced insulin resistance in skeletal muscles, and to investigate whether the glycogen synthase-3 (GSK-3) inhibitor CHIR-637 could restore insulin-stimulated glucose metabolism. Materials and methods: Skeletal muscles were made insulin-resistant by treating male Wistar rats with dexamethasone, a glucocorticoid analogue, for 12 days. Insulin-stimulated glucose uptake, glycogen synthesis and insulin signalling were studied in skeletal muscles in vitro. Results: Dexamethasone treatment decreased the ability of insulin to stimulate glucose uptake, glycogen synthesis and glycogen synthase fractional activity. In addition, the dephosphorylation of glycogen synthase by insulin was blocked. These defects were paralleled by reduced insulin-stimulated protein kinase $\mathrm{B}$ (PKB) and GSK-3 phosphorylation. While expression of PKB, GSK-3 and glycogen synthase was not reduced by dexamethasone treatment, expression of the $\mathrm{p} 85 \alpha$ subunit of phosphatidylinositol 3-kinase (PI 3-kinase) was increased. Inhibition of GSK-3 by CHIR-637 increased glycogen synthase fractional activity in soleus muscle from normal and dexamethasone-treated rats, although the effect was more pronounced in control rats. CHIR-637 did not improve insulin-stimulated glucose uptake in muscles from dexamethasone-treated rats. Conclusions/interpretation: We dem-
\end{abstract}

\footnotetext{
J. Ruzzin · J. Jensen $(\bowtie)$

Department of Physiology,

National Institute of Occupational Health,

P.O. Box 8149 Dep., 0033 Oslo, Norway

e-mail: jorgen.jensen@stami.no

Tel.: +47-23-195243

Fax: +47-23-195204

\section{J. Ruzzin}

Norwegian University of Sport and Physical Education,

Oslo, Norway
}

A. S. Wagman

Medicinal Chemistry Department, Chiron Corporation,

Emeryville, CA, USA onstrated that chronic dexamethasone treatment impairs insulin-stimulated PKB and GSK-3 phosphorylation, which may contribute to insulin resistance in skeletal muscles. Acute pharmacological inhibition of GSK-3 activated glycogen synthase in muscles from dexamethasone-treated rats, but GSK-3 inhibition did not restore insulinstimulated glucose uptake.

Keywords Akt - CHIR-637 - CT20026 - Glucose uptake · Glycogen synthesis - GSK-3 inhibitor ·

PKB phosphorylation

Abbreviations EDL: extensor digitorum longus - G-6-P: glucose 6-phosphate - GSK-3: glycogen synthase kinase-3 . PI 3-kinase: phosphatidylinositol 3-kinase - PKB: protein kinase B - ZDF: Zucker diabetic fatty rat

\section{Introduction}

Glucocorticoids in excess induce insulin resistance. This has been documented in patients with Cushing's syndrome [1], during glucocorticoid treatment [2], in glucocorticoid clinical trials [3], and in conjunction with mental stress [4]. It has even been suggested that high-fat diets cause insulin resistance via increased glucocorticoid production [5]. The receptors for glucocorticoids belong to the nuclear receptor family [6]. When a glucocorticoid binds to its receptor, the receptor translocates to the nucleus, where it binds to glucocorticoid response elements on DNA and regulates transcription of specific genes [7].

Insulin enhances glucose transport by stimulation of GLUT4 translocation from intracellular vesicles to the cell membrane [8]. When insulin binds to its receptor, the latter becomes tyrosine-phosphorylated and activates IRS-1. Tyrosine-phosphorylated IRS- 1 binds the p $85 \alpha$ regulatory subunit of phosphatidylinositol 3-kinase (PI 3-kinase) and the p110 catalytic subunit becomes activated [9]. Protein kinase $\mathrm{B}(\mathrm{PKB})$ is subsequently activated by phosphorylation at $\mathrm{Thr}^{308}$ and $\mathrm{Ser}^{473}$ [9]. Once activated, PKB phosphorylates glycogen synthase kinase-3 (GSK) (GSK-3 $\alpha$ at 
Ser $^{21}$, GSK-3 $\beta$ at Ser ${ }^{9}$ ), deactivating the kinase [10]. GSK3 inactivation promotes glycogen synthase activation and increases glycogen synthesis [11]. Moreover, PKB mediates insulin-stimulated GLUT4 translocation $[12,13]$, but the complete signalling pathway remains unknown.

Skeletal muscles represent the predominant peripheral site of insulin-dependent glucose disposal [14]. Adequate regulation of blood glucose requires that excess glucose is incorporated into skeletal muscle glycogen [15], and insulin resistance in skeletal muscles plays a key role in the development of type 2 diabetes. Chronic treatment with the glucocorticoid analogue dexamethasone decreases insulinstimulated glucose uptake and GLUT4 translocation in skeletal muscle without reducing the total content of GLUT4 [16, 17]. Dexamethasone treatment, in addition, inhibits insulin-stimulated glycogen synthesis and glycogen synthase activation [18, 19].

Many investigations have focused on identifying the insulin signalling steps that are impaired in insulin-resistant muscles and a number of studies have reported reduced activation of PI 3-kinase and PKB [20-23]. However, reduced insulin-stimulated PI 3-kinase activation does not necessarily reduce PKB activation, and insulin was found to promote phosphorylation of PKB normally in insulinresistant muscles despite a decrease in insulin-stimulated IRS-1-associated PI 3-kinase activity activity [24, 25]. Dexamethasone-induced insulin resistance does not alter tyrosine phosphorylation of the insulin receptor $[18,26]$, but inhibits insulin-stimulated IRS-1 associated PI 3-kinase activity [26]. The first aim of the present study was to evaluate the role of PKB and GSK-3 in the development of insulin resistance in skeletal muscles during in vivo treatment with dexamethasone.

Pharmacological inhibition of GSK-3 with highly selective, reversible, cell-permeable small molecules can improve insulin sensitivity in insulin-resistant muscles from Zucker diabetic fatty (ZDF) rats [27-29]. A single administration of a GSK-3 inhibitor in ZDF rats improved glucose disposal and increased glycogen synthase activity in liver and muscles [29]. More interestingly, GSK-3 inhibitors increased insulin-stimulated glucose transport in epitrochlearis and soleus muscles from insulin-resistant ZDF rats, but not from insulin-sensitive lean Zucker rats [27, 28]. The enhancement of insulin-stimulated glucose transport response in insulinresistant muscle may be related to GSK-3's role in the pathogenesis of insulin resistance, and is probably unrelated to the inhibitor's effects on glycogen synthase activation [28]. The second aim of the present study was to investigate whether pharmacological inhibition of GSK-3 improves insulin-stimulated glucose uptake and glycogen synthase activation in skeletal muscles from dexamethasone-treated rats.

\section{Materials and methods}

\section{Animals}

Male Wistar rats (Bk1:Wist; B \& K Universal, Nittedal, Norway) were housed at $21^{\circ} \mathrm{C}$ with a $12: 12 \mathrm{~h}$ light-dark cycle (light from 07.00 to $19.00 \mathrm{~h}$ ) and given free access to chow and tap water. Rats were housed individually for 1 week and were divided in two weight-matched groups $(280.8 \pm 2.9 \mathrm{~g}$ for control rats and $282.9 \pm 2.8 \mathrm{~g}$ for dexamethasone-treated rats, $n=28-29$ ). Rats were submitted to a daily intraperitoneal injection of dexamethasone $(1.0 \mathrm{mg} /$ $\mathrm{kg}$ dissolved in $0.9 \% \mathrm{NaCl}$ ) (Sigma, St Louis, CA, USA) for 12 days. This concentration has previously been reported to induce a state of insulin resistance $[16,26]$. Other rats were injected with $0.9 \% \mathrm{NaCl}$. In the $18 \mathrm{~h}$ preceding the experiment, rats were given $5 \mathrm{~g}$ of chow. The experiments were conducted in conformity with the laws and regulations controlling experiments on live animals in Norway and the European Convention for the Protection of Vertebrate Animals used in Experimental and Other Scientific Purposes.

Incubations and tissue removal

Rats were anaesthetised with an intraperitoneal injection of $\sim 0.5 \mathrm{ml}$ pentobarbital $(50 \mathrm{mg} / \mathrm{ml})$. Soleus strips and intact epitrochlearis muscles were dissected out and mounted on apparatus at their approximate resting length and incubated as described previously [30]. Initially, muscles were preincubated for $\sim 30 \mathrm{~min}$ in $3.5 \mathrm{ml} \mathrm{Krebs}-$ Henseleit buffer containing $5.5 \mathrm{mmol} / 1$ glucose, $2 \mathrm{mmol} / \mathrm{l}$ pyruvate, $5 \mathrm{mmol} / 1$ HEPES and $0.1 \%$ bovine serum albumin, $\mathrm{pH}$ 7.4. After preincubation, muscles were incubated for measurement of glucose uptake, glycogen synthesis, or for analysis of insulin signalling as described below. Incubation buffers were continuously gassed at $95 \%$ oxygen and $5 \%$ carbon dioxide and maintained at $30^{\circ} \mathrm{C}$ in a water bath. Immediately after incubation, muscles were removed from the apparatus, blotted on filter paper, frozen in liquid nitrogen and stored at $-70^{\circ} \mathrm{C}$ until analysis. After dissection of the soleus and epitrochlearis, the extensor digitorum longus (EDL), heart and liver were rapidly removed, frozen in liquid nitrogen and stored at $-70^{\circ} \mathrm{C}$ until analysis. Finally, epididymal fat pads were removed and weighed.

\section{Glucose uptake}

For measurements of glucose uptake, muscles were incubated for $30 \mathrm{~min}$ in Krebs-Henseleit buffer containing $\sim 9.3 \times 10^{6} \mathrm{~Bq} / 12-\left[1,2^{3} \mathrm{H}(N)\right]$-deoxy-D-glucose (specific activity $1.1 \times 10^{15} \mathrm{~Bq} / \mathrm{mol}$; DuPont-New England Nuclear, Boston, MA, USA) and $\sim 3.7 \times 10^{6} \mathrm{~Bq} / 1\left[{ }^{14} \mathrm{C}\right]$-mannitol (specific activity $2.1 \times 10^{12} \mathrm{~Bq} / \mathrm{mol}$; DuPont-New England Nuclear) without or with 3 or $60 \mathrm{nmol} / \mathrm{l}$ of insulin (Actrapid; Novo Nordisk, Bagsværd, Denmark). Freeze-dried muscle samples were weighed and dissolved in $600 \mu \mathrm{l}$ of $\mathrm{KOH} 1 \mathrm{~mol} / 1$ for $20 \mathrm{~min}$ at $70^{\circ} \mathrm{C}$. Then $400 \mu \mathrm{l}$ of the digest was added to $3 \mathrm{ml}$ scintillation solution (Hionic Fluor; Packard Bioscience, Groningen, The Netherlands), mixed, and counted for radioactivity (Tri-Carb 1900 TR; Packard BioScience, Meriden, CT, USA). 
Glycogen synthesis

Glycogen synthesis was measured from the incorporation of $\left[{ }^{14} \mathrm{C}\right]$-glucose into glycogen. Muscles were incubated for $60 \mathrm{~min}$ in Krebs-Henseleit buffer containing $\sim 7.4 \times 10^{6} \mathrm{~Bq} / 1$ of $\mathrm{D}-\left[{ }^{14} \mathrm{C}(\mathrm{U})\right]$-glucose (specific activity $11.2 \times 10^{12} \mathrm{~Bq} / \mathrm{mol}$; DuPont-New England Nuclear) and different insulin concentrations. For analysis of radiolabelled glycogen, muscles were freeze-dried, weighed, and dissolved in $600 \mu \mathrm{l}$ of $\mathrm{KOH} 1 \mathrm{~mol} / 1\left(20 \mathrm{~min}\right.$ at $\left.\sim 70^{\circ} \mathrm{C}\right)$. To $500 \mu \mathrm{l}$ of $\mathrm{KOH}$ digest, $100 \mu \mathrm{l}$ of saturated $\mathrm{Na}_{2} \mathrm{SO}_{4}$ and $100 \mu \mathrm{l}$ glycogen $(25 \mathrm{mg} / \mathrm{ml})$ were added and mixed. Cold $\left(\sim-70^{\circ} \mathrm{C}\right)$ ethanol $(1.5 \mathrm{ml})$ was added and the glycogen was precipitated overnight at $-20^{\circ} \mathrm{C}$. After centrifugation $\left(3,000 \mathrm{~g}\right.$ for $20 \mathrm{~min}$ at $\left.4^{\circ} \mathrm{C}\right)$ the supernatant was discarded and the precipitate was dissolved in $500 \mu \mathrm{l}$ of distilled water for $20 \mathrm{~min}$ at $70^{\circ} \mathrm{C}$, and the glycogen was reprecipitated with addition of cold ethanol $(1 \mathrm{ml})$ and stored for $60 \mathrm{~min}$ at $-20^{\circ} \mathrm{C}$. The new precipitates were dissolved in $300 \mu \mathrm{l}$ of distilled water and $250 \mu \mathrm{l}$ of the solution was added to $3 \mathrm{ml}$ of scintillation solution (Hionic Fluor) and counted for radioactivity (Tri-Carb 1900 TR; Packard, USA).

\section{Glycogen concentration}

For measurements of glycogen in skeletal muscles, $100 \mu \mathrm{l}$ of the KOH digest was neutralised with $25 \mu \mathrm{l}$ acetic acid 7 $\mathrm{mol} / \mathrm{l}$ prior to addition of $500 \mu \mathrm{l}$ acetate buffer $0.3 \mathrm{~mol} / 1$ (pH 4.8) containing $0.2 \mathrm{U} / \mathrm{ml}$ of amyloglucosidase (Boehringer-Mannheim, Indianapolis, IN, USA). The glycogen was hydrolysed at $37^{\circ} \mathrm{C}$ for $3 \mathrm{~h}$ and the glucose formed was determined fluorometrically [31]. Glycogen in liver and heart tissues was hydrolysed in $1 \mathrm{~mol} / 1 \mathrm{HCl}$ for $2.5 \mathrm{~h}$ at $100^{\circ} \mathrm{C}$. Because of the high glycogen concentration in the liver, $100 \mu \mathrm{l}$ of hydrolysate was diluted (1:4) in $1 \mathrm{~mol} / 1$ $\mathrm{HCl}$. The digests were centrifuged $(2,500 \times g$ for $10 \mathrm{~min}$ at $4^{\circ} \mathrm{C}$ ) and glucose units were measured fluorometrically [31].

\section{Glycogen synthase activity}

Glycogen synthase activity was measured in muscles incubated with and without insulin. Glycogen synthase activity was analysed as described before [32]. Glycogen synthase activities were measured without glucose 6phosphate (G-6-P), with $0.17 \mathrm{mmol} / \mathrm{l} \mathrm{G}-6-\mathrm{P}$ and with 12 mmol/1 G-6-P (total activity). The glycogen synthaseindependent activity (\%) was calculated as the activity of the enzyme in the absence of G-6-P divided by the total activity and multiplied by 100 . Glycogen synthase fractional activity (\%) was calculated as the activity of the enzyme with $0.17 \mathrm{mmol} / \mathrm{l} \mathrm{G}-6-\mathrm{P}$ divided by the total activity and multiplied by 100 .
Plasma glucose

Blood was taken from the vein of the tail between 10.00 and $11.00 \mathrm{~h}$. Blood $(20 \mu \mathrm{l})$ was added to $500 \mu \mathrm{l}$ of $0.4 \mathrm{~mol} / \mathrm{l}$ PCA on ice. For analysis, samples were centrifuged $\left(2,500 \times \mathrm{g}\right.$ for $10 \mathrm{~min}$ at $\left.4^{\circ} \mathrm{C}\right)$ and glucose units were measured fluorometrically [31].

\section{Western blot analysis}

Skeletal muscles were weighed and homogenised (1 mg w/w, $25 \mu \mathrm{l}$ ) in ice-cold buffer containing $50 \mathrm{mmol} / \mathrm{l}$ HEPES, $150 \mathrm{mmol} / \mathrm{l} \mathrm{NaCl}, 10 \mathrm{mmol} / 1 \mathrm{Na}_{4} \mathrm{P}_{2} \mathrm{O}_{7}, 30 \mathrm{mmol} / \mathrm{l} \mathrm{NaF}, 1$ $\mathrm{mmol} / 1 \mathrm{Na}_{3} \mathrm{VO}_{4}, 10 \mathrm{mmol} / 1$ EDTA, $2.5 \mathrm{mmol} / 1$ benzamidine, $0.5 \mu \mathrm{g} / 10 \mathrm{mg}$ muscle of protease inhibitor cocktail (Sigma P-8430) and 1\% Triton X-100, pH 7.4. Homogenates were rotated for $1 \mathrm{~h}$ at $4{ }^{\circ} \mathrm{C}$ and centrifuged $(11,500 \times g$ at $4^{\circ} \mathrm{C}$ for $10 \mathrm{~min}$ ), as described before [33]. Protein concentration in supernatants was determined by a DC protein assay (Bio-Rad Laboratories, Hercules, CA, USA) according to the instruction manual. Supernatants were diluted to a protein concentration of $3 \mu \mathrm{g} / \mu \mathrm{l}$, aliquoted, and stored at $-70^{\circ} \mathrm{C}$.

For electrophoresis, aliquots were prepared with Laemmli buffer [34], heated at $95^{\circ} \mathrm{C}$ for $5 \mathrm{~min}$ to completely disociate proteins, and centrifuged at $22000 \times g$ for $15 \mathrm{~s}$. Muscle proteins were separated by electrophoresis in either 8 or 10\% SDS-PAGE. Transfer of proteins from the gel onto the polyvinylidene difluoride (PVDF) membrane was performed for $1 \mathrm{~h}$ at $200 \mathrm{~V}$ in a Mini Trans-Blot cell with a Bio-Ice cooling unit (Bio-Rad Laboratories). The transfer buffer contained $25 \mathrm{mmol} / 1$ Tris, $192 \mathrm{mmol} / 1$ glycine and $10 \%$ methanol. Membranes were washed $(3 \times 10 \mathrm{~min})$ in PBS-T $\left(80 \mathrm{mmol} / 1 \mathrm{Na}_{2} \mathrm{HPO}_{4}, 20 \mathrm{mmol} / \mathrm{l}\right.$ $\mathrm{NaH}_{2} \mathrm{PO}_{4}, 100 \mathrm{mmol} / 1 \mathrm{NaCl}, 0.1 \%$ Tween 20 ). To avoid non-specific binding of antibody to the PVDF, membranes were blocked in PBS-T containing 5\% non-fat milk or 5\% BSA (for anti-phosphotyrosine) for $2 \mathrm{~h}$ at room temperature. After blocking, membranes were washed in PBS-T $(2 \times 30 \mathrm{~s})$, and incubated overnight at $4^{\circ} \mathrm{C}$ with the primary antibody. After washing in PBS-T $(6 \times 10 \mathrm{~min})$, membranes were incubated with the appropriate secondary antibody conjugated to horseradish peroxidase (HRP) for $1 \mathrm{~h}$ at room temperature, and washed again $(6 \times 10 \mathrm{~min})$. Antibody binding was detected by enhanced chemiluminescence (ECL; Amersham Pharmacia Biotech, Little Chalfont, Buckinghamshire, UK) as described by the manufacturer. Blots were scanned (Scan Jet IIcx; Hewlett Packard, Palo Alto, CA, USA) and signals quantified by densitometry with Scion Image software (Scion Corporation, Frederick, MD, USA).

\section{Antibodies}

Anti-phosphotyrosine, anti-PKB $\alpha$, anti-PKB $\beta$ and antiGSK- $3 \alpha / \beta$ were from Upstate Biotechnology (Lake Placid, 
NY, USA). Anti-phospho-GSK $3 \alpha / \beta\left(\operatorname{Ser}^{21} / \operatorname{Ser}^{9}\right)$, anti-phospho-PKB $\left(\mathrm{Ser}^{4+3}\right)$, anti-phospho-PKB $\left(\mathrm{Thr}^{308}\right)$ and antiphospho-p $70^{\mathrm{s} 6 \mathrm{k}}$ were from Cell Signalling (Beverly, MA, USA). Anti-phosphoglycogen synthase ( $\mathrm{Ser}^{645}, \mathrm{Ser}^{649}$, $\mathrm{Ser}^{653}, \mathrm{Ser}^{657}$ ) was from Oncogene (San Diego, CA, USA). $\mathrm{p} 85 \alpha$ was a gift from P. Shepherd (University College London, UK). Antibodies against glycogen synthase and GLUT4 were generous gifts from Oluf Pedersen (Copenhagen, Denmark) and David James (Sydney, Australia), respectively. Anti-rabbit HRP-linked antibody was from New England Biolabs (Beverly, MA, USA). Anti-sheep and anti-mouse HRP-linked antibodies were from Upstate Biotechnology (Lake Placid, NY, USA).

\section{GSK-3 inhibitor}

The GSK-3 inhibitor CHIR-637 (also known as CT20026) was obtained from Chiron Corporation (Emeryville, CA, USA). CHIR-637, a low-molecular weight (531 Da) small molecule, is an ATP-competitive inhibitor of GSK-3 $\beta$ giving an $\mathrm{IC}_{50}$ of $4 \mathrm{nmol} / \mathrm{l}$ in a cell-free binding assay [35]. This inhibitor is approximately equipotent against both isoforms of GSK-3 $(\alpha / \beta)$. Like other GSK-3 inhibitors in this class, it exhibits $>2,500$-fold selectivity against a panel of 16 other protein kinases, including cdc 2 and erk2, which are the closest homologues of GSK-3. To the best of our knowledge, CHIR-637 does not interfere with kinases (with the exception of GSK-3) that are involved in the insulin signalling pathway. Demonstrating excellent membrane permeability, glycogen synthase activation was stimulated two- to three-fold above basal in CHIR-637treated insulin receptor-expressing CHO-IR cells. The concentration of GSK-3 inhibitor causing half-maximal glycogen synthase stimulation $\left(\mathrm{EC}_{50}\right)$ in CHO-IR cells was $66 \mathrm{nmol} / 1$ [35], which is similar to the $\mathrm{EC}_{50}$ observed in soleus muscles in this study (data not shown).

CHIR-637 was diluted in DMSO to obtain a $10 \mathrm{mmol} / \mathrm{l}$ stock solution and stored at $-20^{\circ} \mathrm{C}$. Before experiments, the liquefied stock solution was sonicated and further dissolved in DMSO and added to incubation buffers at the concentration to study. In experiments with CHIR-637, $0.1 \%$ DMSO was present in exposed and control muscles. A concentration of $500 \mathrm{nmol} / 1$ GSK-3 inhibitor was found to fully activate glycogen synthase in cells (data not shown).
Table 2 Glycogen concentration ( $\mathrm{mmol} / \mathrm{kg}$ dry weight) in soleus, epitrochlearis, liver and heart from control and dexamethasonetreated rats

\begin{tabular}{lll}
\hline & Control rats & Dexamethasone-treated rats \\
\hline Soleus $(n=11)$ & $115.9 \pm 3.8$ & $159.4 \pm 9.6^{\mathrm{a}}$ \\
Epitrochlearis ${ }^{\mathrm{b}}(n=10)$ & $154.7 \pm 5.6$ & $197.4 \pm 13.4^{\mathrm{a}}$ \\
Liver $(n=13)$ & $182.2 \pm 32.8$ & $569.2 \pm 65.8^{\mathrm{a}}$ \\
Heart $(n=13)$ & $132.7 \pm 10.3$ & $137.7 \pm 18.8$ \\
\hline
\end{tabular}

Values are mean \pm SEM

${ }^{\mathrm{a}}$ Significantly different from control rats, $p<0.003$

${ }^{\mathrm{b}}$ Incubated with $3 \mathrm{nmol} / \mathrm{l}$ for $30 \mathrm{~min}$

\section{Statistics}

Data are presented as means \pm SEM. Comparisons were initiated by ANOVA. Least significant difference tests were performed post hoc. A value of $p<0.05$ was considered statistically significant.

\section{Results}

Characteristics of rats treated with dexamethasone

As observed by others, glucocorticoid excess caused slight hyperglycaemia and muscle atrophy (Table 1). Rats treated with dexamethasone had lower body weight and epididymal fat pad weight than control rats (Table 1). After fasting, the glycogen concentration was slightly higher in skeletal muscles of dexamethasone-treated rats than control rats (Table 2). The daily food consumption in control and dexamethasone-treated rats was $23.1 \pm 1.8(n=12)$ and $15.5 \pm 1.0 \mathrm{~g}$ $(n=8)$, respectively.

\section{Glucose uptake}

In the soleus, insulin-stimulated glucose uptake was lower in dexamethasone-treated rats than in control rats at $3 \mathrm{nmol} / 1$ $(50 \%)$ and $60 \mathrm{nmol} / 1$ insulin (38\%) (Fig. 1a). In epitrochlearis, dexamethasone inhibited insulin-stimulated glucose uptake by $40 \%$ at $3 \mathrm{nmol} / 1$ and $25 \%$ at $60 \mathrm{nmol} / 1$ insulin (Fig. 1b).

Table 1 Characteristics of rats studied

\begin{tabular}{lllll}
\hline & Plasma glucose $(\mathrm{mmol} / \mathrm{l})$ & Body weight $(\mathrm{g})$ & EDL $(\mathrm{mg})$ & Epididymal fat pad $(\mathrm{g})$ \\
\hline Control rats & $5.1 \pm 0.2(n=7)$ & $321.9 \pm 5.0(n=29)$ & $134.0 \pm 4.0(n=6)$ & $5.6 \pm 0.4(n=9)$ \\
Dexamethasone-treated rats & $5.5 \pm 0.2^{\mathrm{a}}(n=9)$ & $233.4 \pm 3.2^{\mathrm{a}}(n=28)$ & $99.7 \pm 6.0^{\mathrm{a}}(n=6)$ & $4.5 \pm 0.3^{\mathrm{a}}(n=9)$ \\
\hline
\end{tabular}

Plasma glucose was determined after 8 days of dexamethasone or saline treatment

Values are mean \pm SEM

$E D L$ extensor digitorum longus muscle

${ }^{a}$ Significantly different from control rats, $p<0.006$ 
a

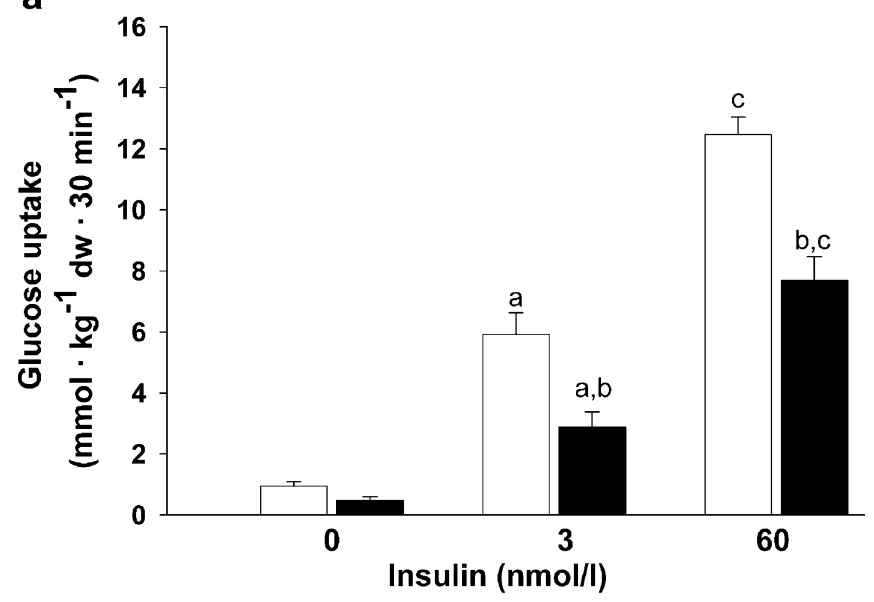

b

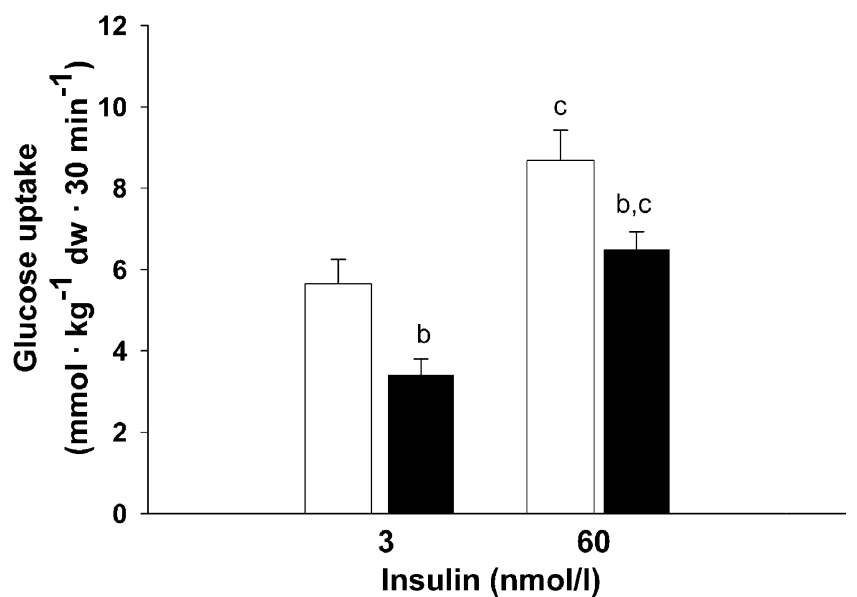

Fig. 1 Effects of dexamethasone on glucose uptake in skeletal muscles. Muscles from control (open bars) and dexamethasonetreated (filled bars) rats were incubated for $30 \mathrm{~min}$ with different concentrations of insulin. a Effect of insulin on glucose uptake in soleus from control and dexamethasone-treated rats. b Effect of insulin on glucose uptake in epitrochlearis from control and dexamethasone-treated rats. $d w$ dry weight. Values are mean \pm SEM. Number per group: $n=7$ for soleus; $n=10$ for epitrochlearis. ${ }^{\mathrm{a}} p<0.003$ vs muscle incubated without insulin from rats exposed to similar treatment; ${ }^{b} p<0.01$ vs muscle from control rats incubated with a similar insulin concentration; ${ }^{\mathrm{c}} p<0.002$ vs muscle incubated with $3 \mathrm{nmol} / 1$ from rats exposed to similar treatment

\section{Glycogen synthesis}

Insulin-stimulated glycogen synthesis was decreased in soleus from dexamethasone-treated rats, whereas basal glycogen synthesis was not significantly reduced. Rates of glycogen synthesis were reduced by $\sim 70 \%$ at physiological and supraphysiological insulin concentrations in soleus from dexamethasone-treated rats compared with control rats (Fig. 2a).

Glycogen synthase activity and glycogen synthase phosphorylation

Insulin increased glycogen synthase fractional activity (Fig. 2b) and glycogen synthase activity in the independent form (data not shown) in soleus from control rats. In muscles from dexamethasone-treated rats, insulin was unable to increase glycogen synthase fractional activity (Fig. 2b) and glycogen synthase activity in the independent form (data not shown). In agreement with these data, insulin decreased glycogen synthase phosphorylation $\left(\mathrm{Ser}^{645}, \mathrm{Ser}^{649}, \mathrm{Ser}^{653}, \mathrm{Ser}^{657}\right)$ in soleus from control rats, but insulin did not stimulate dephosphorylation of glycogen synthase soleus from dexamethasone-treated rats (Fig. 2c). Glycogen synthase total activity was similar in soleus from control and dexamethasone-treated rats (data not shown).

Effects of dexamethasone on expression of insulin signalling proteins

Expression of glycogen synthase, $\mathrm{PKB} \alpha, \mathrm{PKB} \beta, \mathrm{GSK}-3 \alpha$ and GSK- $3 \beta$, as determined by quantification on blots, was similar in control and dexamethasone-treated rats (Fig. 3). Interestingly, expression of the $\mathrm{p} 85 \alpha$ subunit of PI 3-kinase was $30 \%$ higher in dexamethasone-treated rats than in control rats $(130.0 \pm 7.7$ and $100.0 \pm 3.9 \%$ in dexamethasonetreated and control rats, respectively; $n=7$ in each group, $p<0.002)$. GLUT4 expression was similar in soleus from control and dexamethasone-treated rats. In epitrochlearis, GLUT4 expression was higher in muscles from dexamethasone-treated rats than in control rats $(183.7 \pm 23.3$ vs $100.0 \pm 12.3 \%$ in dexamethasone-treated and control rats, respectively; $n=7$ in each group, $p<0.0001$ ).

Tyrosine phosphorylation of insulin receptor

Insulin increased tyrosine phosphorylation of the insulin receptor to similar extents in soleus muscles from control and dexamethasone-treated rats (Fig. 4).

\section{PKB phosphorylation}

In the basal state, PKB $\operatorname{Ser}^{473}$ phosphorylation was undetectable in control and dexamethasone-treated rats (Fig. 5a). Insulin-stimulated PKB Ser ${ }^{473}$ phosphorylation was reduced in soleus and epitrochlearis from dexamethasone-treated rats compared with control rats (Fig. 5a,b). $\mathrm{PKB} \mathrm{Thr}^{308}$ phosphorylation was investigated at $60 \mathrm{nmol} / \mathrm{l}$ insulin and was found to be decreased in soleus muscles from dexamethasone-treated rats $(100.0 \pm 10.0$ and $62.6 \pm 5.4 \%$ in control and dexamethasone-treated rats, respectively; $n=7$ in each group, $p<0.0001)$. PKB $\mathrm{Th}^{308}$ phosphorylation was not detectable in the absence of insulin. Phosphorylation of $\mathrm{p} 70^{\mathrm{S} 6 \mathrm{~K}}$, another PI 3-kinase downstream signalling protein, was reduced at $\mathrm{Thr}^{389}$ by $\sim 65 \%$ in soleus from dexamethasone-treated rats incubated with 60 $\mathrm{nmol} / \mathrm{l}$ insulin $(100.0 \pm 22.0$ and $34.9 \pm 3.9 \%$ in control and dexamethasone-treated rats, respectively; $n=7$ in each group, $p<0.0001)$. Phosphorylation of $\mathrm{p}^{3} 0^{\mathrm{S} 6 \mathrm{~K}}$ at $\mathrm{Th}^{389}$ was not detectable in the absence of insulin. 
a

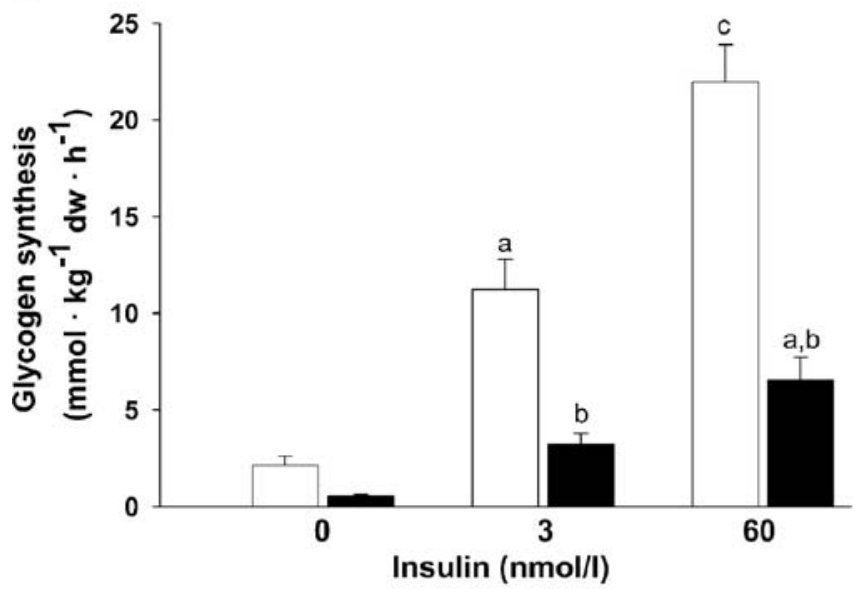

c b

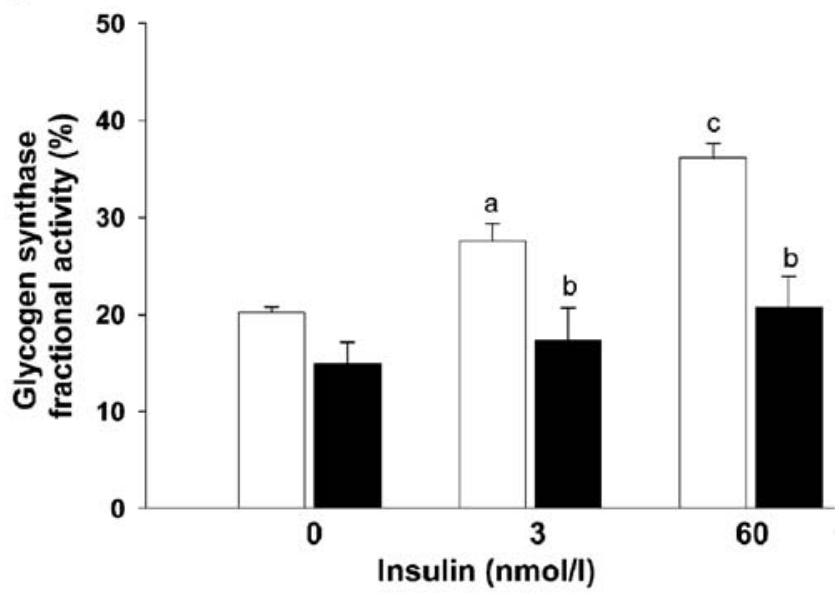

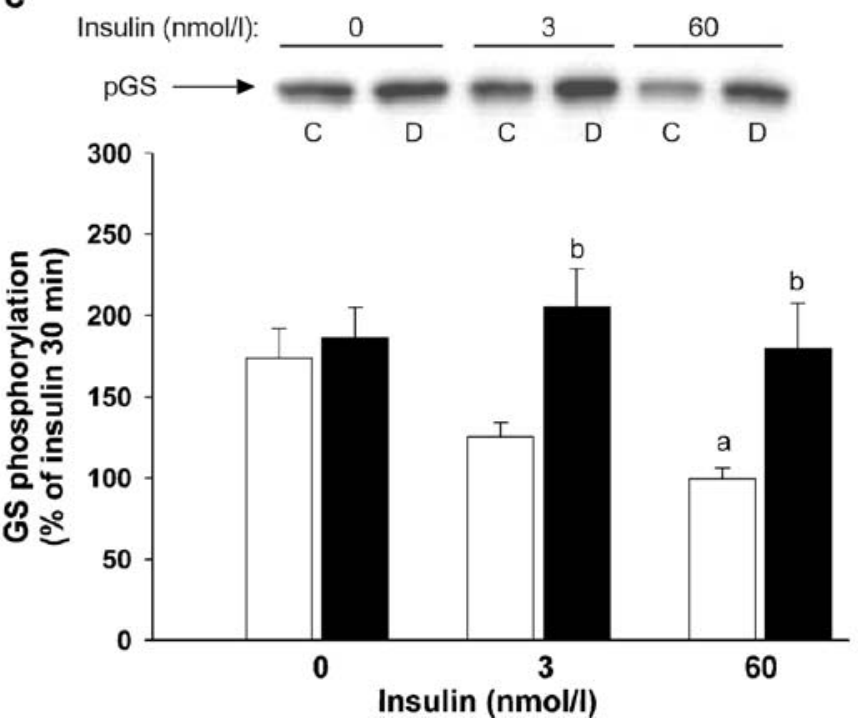

Fig. 2 Effects of dexamethasone on glycogen synthesis and glycogen synthase activation in soleus muscles. Soleus muscles from control (open bars) and dexamethasone-treated (filled bars) rats were incubated with a tracer amount of ${ }^{14} \mathrm{C}$ glucose for $60 \mathrm{~min}$ in the presence of 0,3 and $60 \mathrm{nmol} / 1$ insulin. For glycogen synthase phosphorylation, soleus muscles were incubated for $30 \mathrm{~min}$. Soleus muscles from control rats incubated for $30 \mathrm{~min}$ with $60 \mathrm{nmol} / 1$ insulin were set at $100 \%$ and all values were calculated as a percentage of this. a Effect of insulin on glycogen synthesis in control and dexamethasone-treated rats. b Effect of insulin on

\section{Phosphorylation of GSK- $3 \alpha$ and GSK-3 $\beta$}

In the basal state, phosphorylation of GSK-3 $\alpha \operatorname{Ser}^{21}$ and phosphorylation of GSK-3 $\beta$ Ser $^{9}$ were similar in soleus from control and dexamethasone-treated rats (Fig. 6a,b). In both groups, insulin increased GSK-3 $\alpha$ Ser $^{21}$ phosphorylation and GSK-3 $\beta$ Ser $^{9}$ phosphorylation in a dose-dependent manner (Fig. 6a,b). Insulin-stimulated GSK-3 $\alpha$ Ser $^{21}$ and GSK-3 $\beta$ Ser $^{9}$ phosphorylation were, however, significantly reduced in dexamethasone-treated rats at $3 \mathrm{nmol} /$ 1 insulin ( $30 \%$ for GSK-3 $\alpha$ Ser $^{21}$ phosphorylation and $\sim 33 \%$ for GSK-3 $\beta$ Ser $^{9}$ phosphorylation) and at $60 \mathrm{nmol} / 1$ glycogen synthase fractional activity in control and dexamethasonetreated rats. c Effect of insulin on glycogen synthase phosphorylation in control and dexamethasone-treated rats. $d w$ dry weight, $C$ control, $D$ dexamethasone-treated $G S$ glycogen synthase $p G S$ glycogen synthase phosphorylation. Values are mean \pm SEM. $n=4-14$ for each group. ${ }^{a} p<0.04$ vs muscle incubated without insulin from rats exposed to similar treatment; ${ }^{b} p<0.007$ vs muscle from control rats incubated with a similar insulin concentration; ${ }^{\mathrm{c}} p<0.02$ vs muscle incubated with $3 \mathrm{nmol} / 1$ from rats exposed to similar treatment

of insulin ( $23 \%$ for GSK-3 $\alpha$ Ser $^{21}$ phosphorylation and $\sim 26 \%$ for GSK-3 $\beta$ Ser$^{9}$ phosphorylation) (Fig. $6 a, b$ ).

\section{Effects of CHIR-637 on glycogen synthase activation}

CHIR-637 increased glycogen synthase fractional activity in soleus from control and dexamethasone-treated rats (Fig. 7a,b). However, incubation with CHIR-637 did not increase glycogen synthase fractional activity to a similar extent in soleus muscles from dexamethasone-treated and control rats $(p<0.05)$. As expected from the glycogen synthase fractional activity data, CHIR-637 treatment caused 


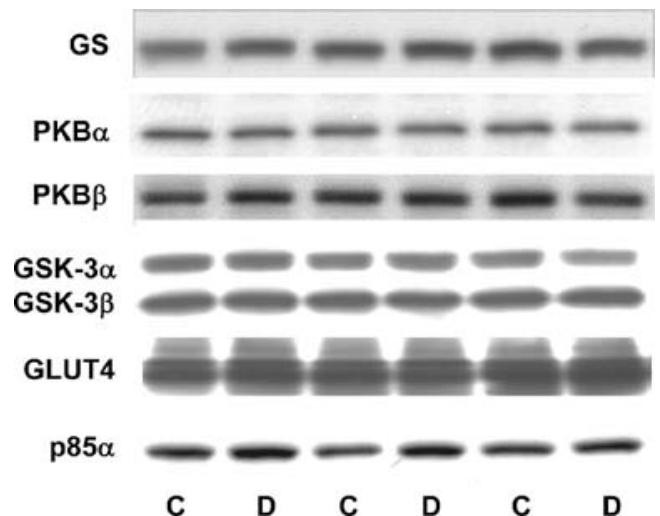

Fig. 3 Effects of dexamethasone on expression of insulin signalling protein in soleus muscles. Blots showing expression of different proteins in soleus muscles from control $(C)$ and dexamethasonetreated $(D)$ rats. Expression of the different proteins was quantified by Western blot in muscles from seven control and seven dexamethasone-treated rats

dephosphorylation of glycogen synthase in soleus from control and dexamethasone-treated rats (Fig. 7c,d).

Effects of CHIR-637 on insulin-stimulated glucose uptake and PKB phosphorylation

CHIR-637 did not change basal glucose uptake (Fig. 8a,b). More importantly, CHIR-637 did not increase insulin-stim-
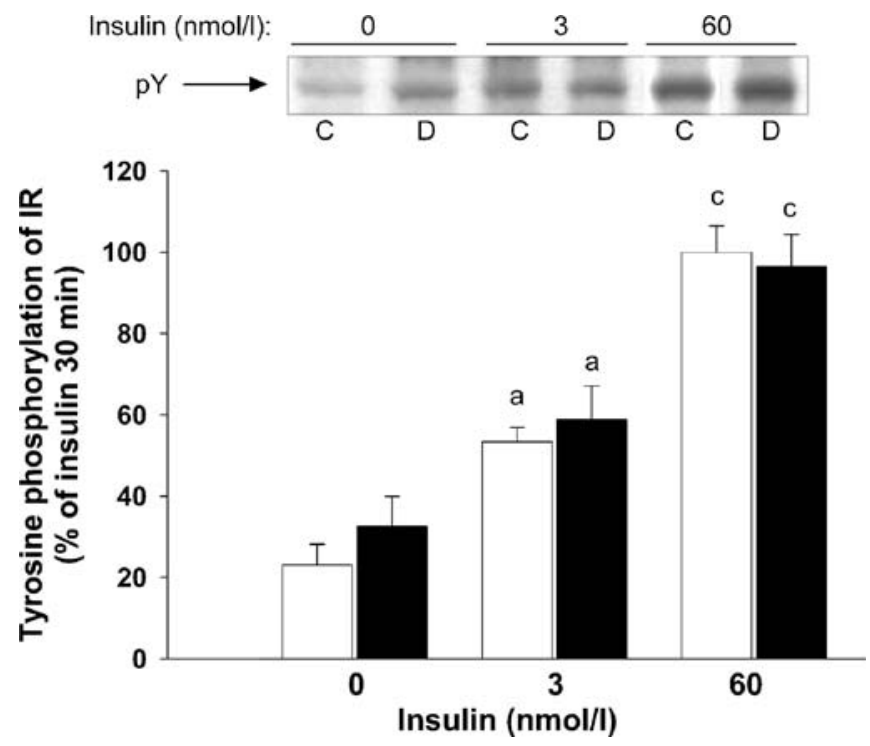

Fig. 4 Effects of dexamethasone on insulin receptor tyrosine phosphorylation in soleus muscles. Soleus muscles from control $(C$, open bars) and dexamethasone-treated ( $D$, filled bars) rats were incubated with 0,3 or $60 \mathrm{nmol} / 1$ insulin for $30 \mathrm{~min}$. Soleus muscles from control rats incubated for $30 \mathrm{~min}$ with $60 \mathrm{nmol} / 1$ insulin were set at $100 \%$ and all values were calculated as a percentage of this. $I R$ Insulin receptor, $p Y$ tyrosine phosphorylation values are mean \pm SEM. $n=4-6$ for each group. ${ }^{a} p<0.03$ vs muscle incubated without insulin from rats exposed to similar treatment; ${ }^{\mathrm{c}} p<0.002$ vs muscle incubated with $3 \mathrm{nmol} / \mathrm{l}$ from rats exposed to similar treatment a

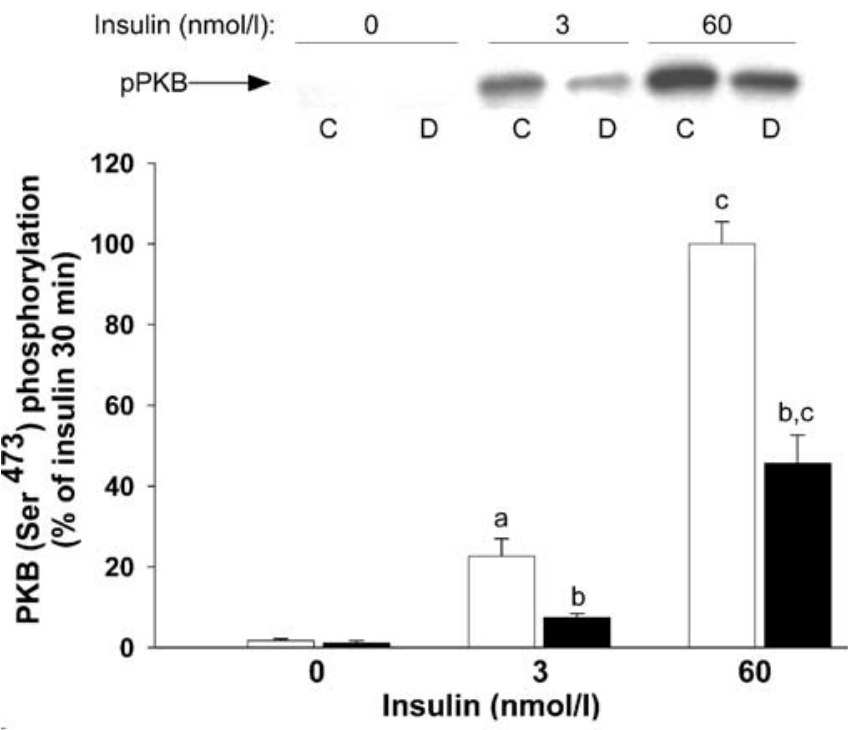

b
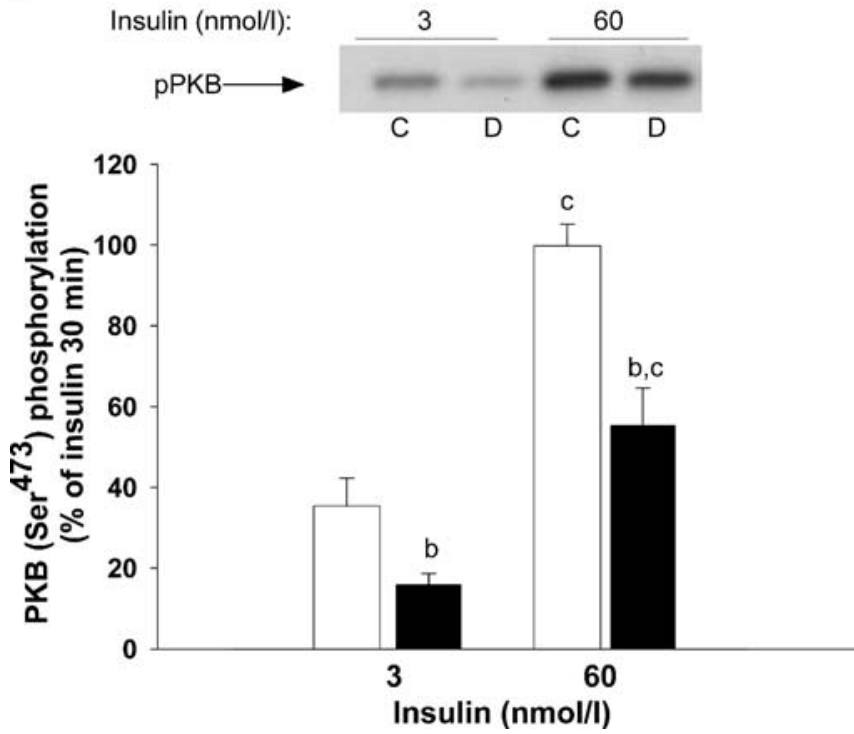

Fig. 5 Effects of dexamethasone on PKB phosphorylation in skeletal muscles. Muscles from control $(C$, open bars) and dexamethasone-treated $(D$, filled bars) rats were incubated for $30 \mathrm{~min}$ with different concentrations of insulin. Muscles from control rats incubated for $30 \mathrm{~min}$ with $60 \mathrm{nmol} / \mathrm{l}$ insulin were set at $100 \%$ and all values were calculated as a percentage of this. a Effect of insulin on $\mathrm{PKB}$ phosphorylation in soleus from control and dexamethasonetreated rats. b Effect of insulin on PKB phosphorylation in epitrochlearis from control and dexamethasone-treated rats. Values are mean \pm SEM. $n=7-9$ for soleus and $n=6-7$ for epitrochlearis. ${ }^{\mathrm{a}} p<0.005$ vs muscle incubated without insulin from rats exposed to similar treatment; ${ }^{b} p<0.05$ vs muscle incubated without CHIR637 and with a similar insulin concentration; ${ }^{c} p<0.0001$ vs muscle incubated with $3 \mathrm{nmol} / 1$ from rats exposed to similar treatment

ulated glucose uptake (Fig. 8a,b) and PKB phosphorylation (Fig. 8c,d) in soleus muscles from control or dexamethasone-treated rats. In epitrochlearis, pretreatment with CHIR-637 did not increase insulin-stimulated glucose uptake in control or dexamethasone-treated rats (data not shown). 

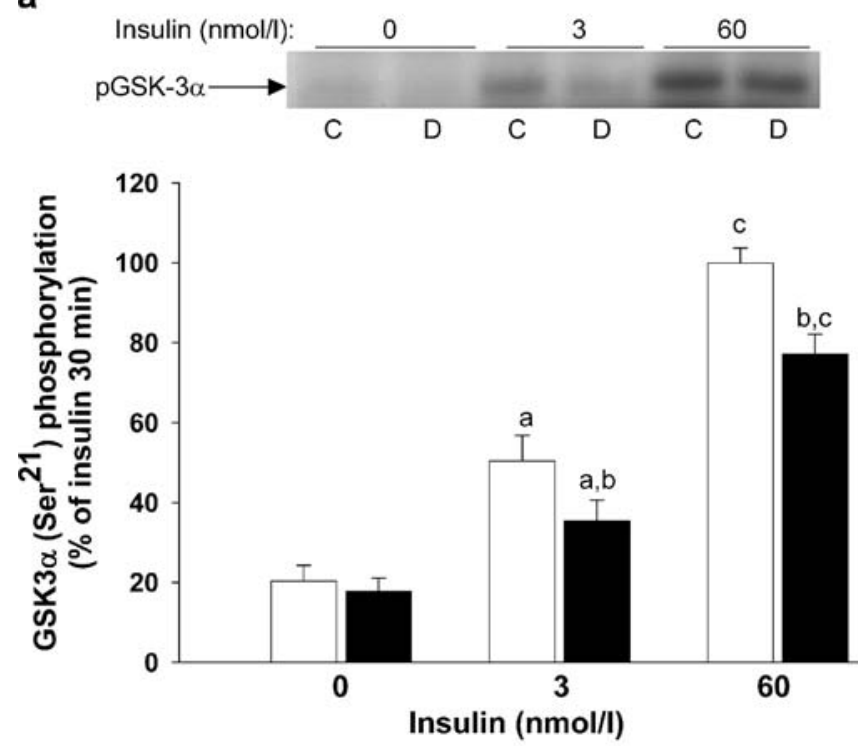

b
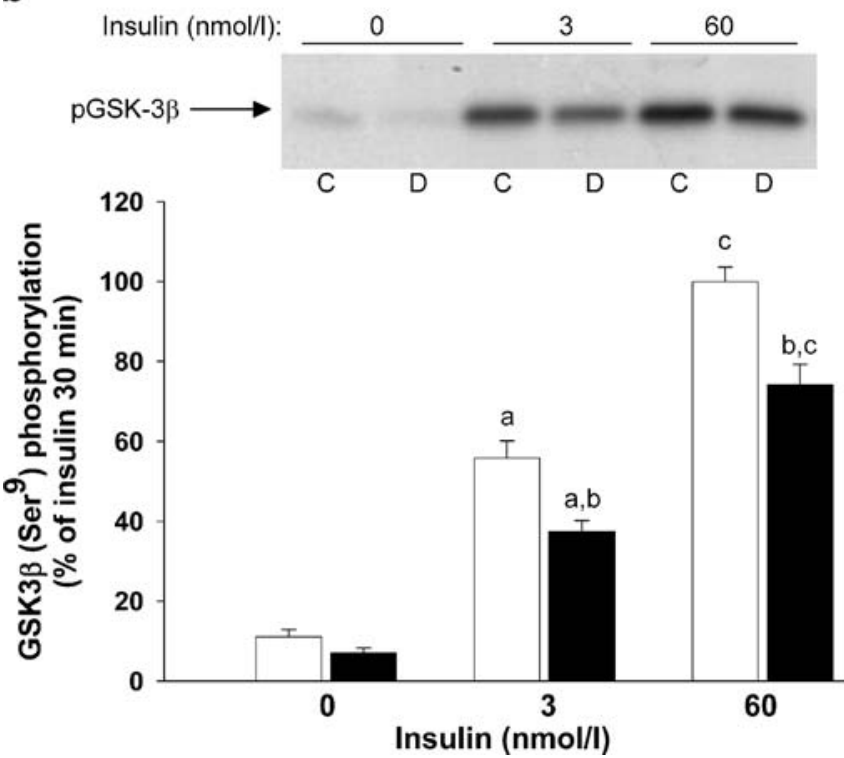

Fig. 6 Effects of dexamethasone on GSK-3 $\alpha$ phosphorylation and GSK-3 $\beta$ phosphorylation in soleus muscles. Soleus muscles from control ( $C$, open bars) and dexamethasone-treated $(D$, filled bars) rats were incubated with 0,3 or $60 \mathrm{nmol} / 1$ insulin for $30 \mathrm{~min}$. For GSK-3 phosphorylation, soleus from control rats incubated for $30 \mathrm{~min}$ with $60 \mathrm{nmol} / 1$ insulin were set at $100 \%$ and all values were calculated as a percentage of this. a Effect of insulin on GSK-3 $\alpha$ phosphorylation in control and dexamethasone-treated rats. b Effect of insulin on GSK-3 $\beta$ phosphorylation in control and dexamethasone-treated rats. Values are mean \pm SEM. $n=11$ for each group. ${ }^{\mathrm{a}} p<0.01$ vs muscle incubated without insulin from rats exposed to similar treatment; ${ }^{\mathrm{b}} p<0.03$ vs muscle from control rats incubated with a similar insulin concentration; ${ }^{c} p<0.0001$ vs. muscle incubated with $3 \mathrm{nmol} / 1$ from rats exposed to similar treatment

\section{Discussion}

Glucocorticoid-induced insulin resistance was confirmed by a $30-50 \%$ reduction in insulin-stimulated glucose uptake and a $\sim 70 \%$ reduction in insulin-stimulated glyco- gen synthesis, in agreement with previous studies [16, 18] We report that dexamethasone treatment decreases insulin-stimulated PKB and GSK-3 phosphorylation and completely blocks the ability of insulin to dephosphorylate and activate glycogen synthase, without reducing expression of these proteins. Pharmacological inhibition of GSK-3 increased glycogen synthase fractional activity in muscles from dexamethasone-treated rats, but did not improve insulin-stimulated glucose uptake.

Dexamethasone abolished insulin's ability to increase glycogen synthase fractional activity and to dephosphorylate glycogen synthase at $\mathrm{Ser}^{645}, \mathrm{Ser}^{649}, \mathrm{Ser}^{653}, \mathrm{Ser}^{657}$. GSK-3 phosphorylates these sites, which are the most important for regulation of glycogen synthase activity [11], and insulin reduced glycogen synthase phosphorylation at these sites by $\sim 50 \%$ in soleus from normal rats. The fact that insulin did not dephosphorylate and activate glycogen synthase in muscles from dexamethasone-treated rats shows that glycogen synthesis is more severely affected than glucose uptake. Glycogen content is a strong regulator of glycogen synthase activity [36] and glycogen content was slightly higher in muscles from dexamethasone-treated rats, as expected $[19,37]$. The glycogen concentration in muscles from dexamethasone-treated rats was, however, not above the content found in non-fasted rats, in which insulin activates glycogen synthase [38]. High glycogen content, therefore, does not explain the inability to dephosphorylate and activate glycogen synthase activation during insulin stimulation.

In the present study, dexamethasone treatment reduced insulin-stimulated PKB Ser ${ }^{473}$ and $\mathrm{Thr}^{308}$ phosphorylation by about $50 \%$. In skeletal muscles, $\mathrm{PKB} \beta$ and $\mathrm{PKB} \alpha$ are the two major isoforms. PKB $\beta$ seems to regulate insulinstimulated glucose uptake $[12,13]$, whereas $\operatorname{PKB} \alpha$ seems to regulate muscle growth [39]. The phospho-specific antibodies against PKB Ser ${ }^{473}$ and PKB Thr ${ }^{308}$ bind to both isoforms, and it is not possible to separate them on blots. Previous studies have reported reduced PKB activity in diabetic Goto-Kakizaki rats [22] and human subjects with type 2 diabetes mellitus [23]. However, other studies have shown normal PKB phosphorylation in insulin-resistant muscles despite decreased insulin-stimulated IRS-1 associated PI 3-kinase activity [24, 25]. A weakness of the present study is that we have only investigated the effect of a high concentration of dexamethasone on PKB phosphorylation, but our data convincingly show reduced insulin-stimulated PKB phosphorylation in insulin-resistant muscles from dexamethasone-treated rats. Further studies have to confirm whether similar impairments occur in humans during clinical treatment with glucocorticoids.

Insulin-stimulated phosphorylation of GSK-3 $\alpha$ and GSK- $3 \beta$ was reduced in muscles from dexamethasonetreated rats. Despite a reduction in insulin-stimulated GSK-3 phosphorylation by about 30\% compared with control rats, insulin still elicited a significant increase in GSK-3 phosphorylation in soleus from dexamethasonetreated rats. The fact that insulin-stimulated glycogen synthase activation and dephosphorylation were completely abolished in dexamethasone-treated rats seems, therefore, 


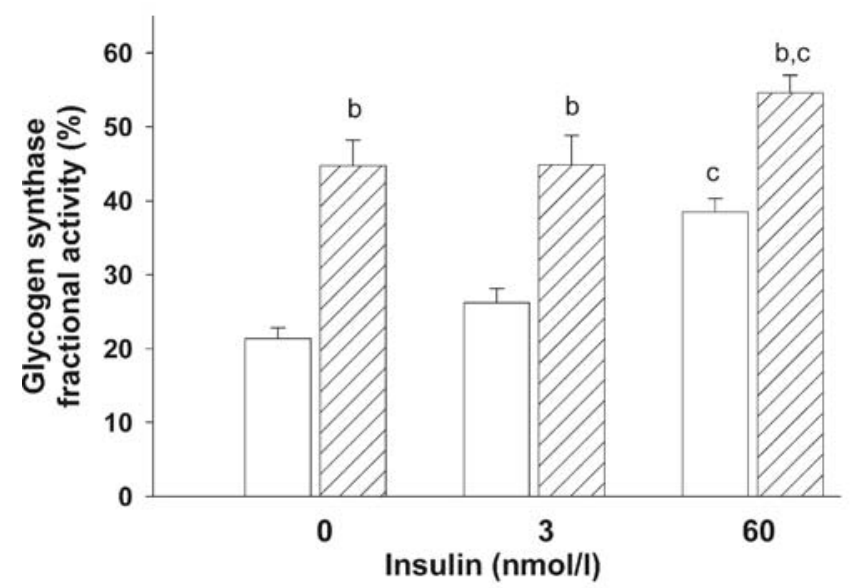

C
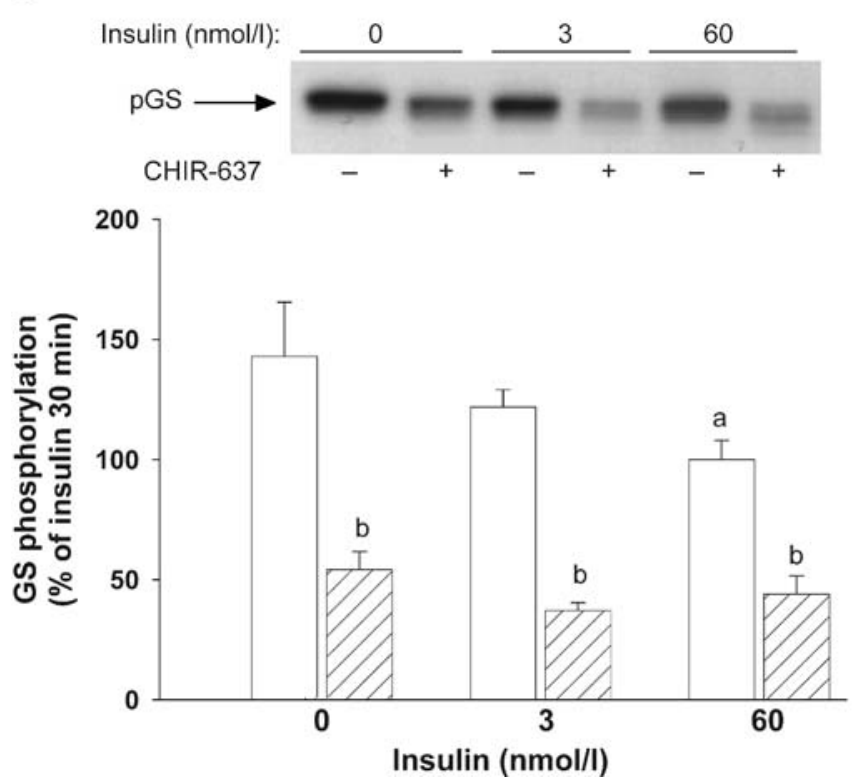

Fig. 7 Effects of CHIR-637 on glycogen synthase fractional activity and glycogen synthase phosphorylation. Soleus muscles from control (open bars) and dexamethasone-treated (filled bars) rats were preincubated for $60 \mathrm{~min}$ without or with (hatched bars) $500 \mathrm{nmol} / 1 \mathrm{CHIR}-637$. After this incubation, soleus muscles were incubated for an additional $30 \mathrm{~min}$ in the presence or absence of $500 \mathrm{nmol} / \mathrm{l} \mathrm{CHIR-637}$ and with 0,3 or $60 \mathrm{nmol} / 1$ of insulin. For glycogen synthase phosphorylation, soleus muscles incubated for $30 \mathrm{~min}$ with $60 \mathrm{nmol} / \mathrm{l}$ insulin and without CHIR-637 were set at $100 \%$ and other values were calculated as percentages of this. a Effects of CHIR-637 on glycogen synthase fractional activity in

to be explained only in part by increased GSK-3 activity. We suggest that dexamethasone treatment also impairs activation of protein phosphatase-1, and therefore dephosphorylation of glycogen synthase in response to insulin.

Glucocorticoid receptors regulate DNA transcription, affecting the expression of various proteins. Reduced expression of PKB [40], reduced expression of glycogen synthase [41] or increased expression of GSK-3 [42] causes insulin resistance. In the present study, dexamethasone did not affect expression of $\mathrm{PKB} \alpha, \operatorname{PKB} \beta, \mathrm{GSK}-3 \alpha$, b

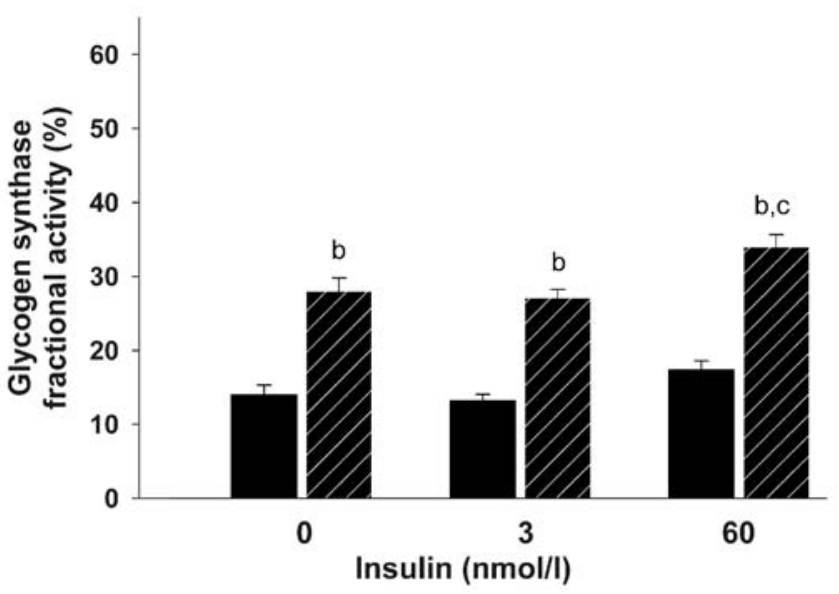

d
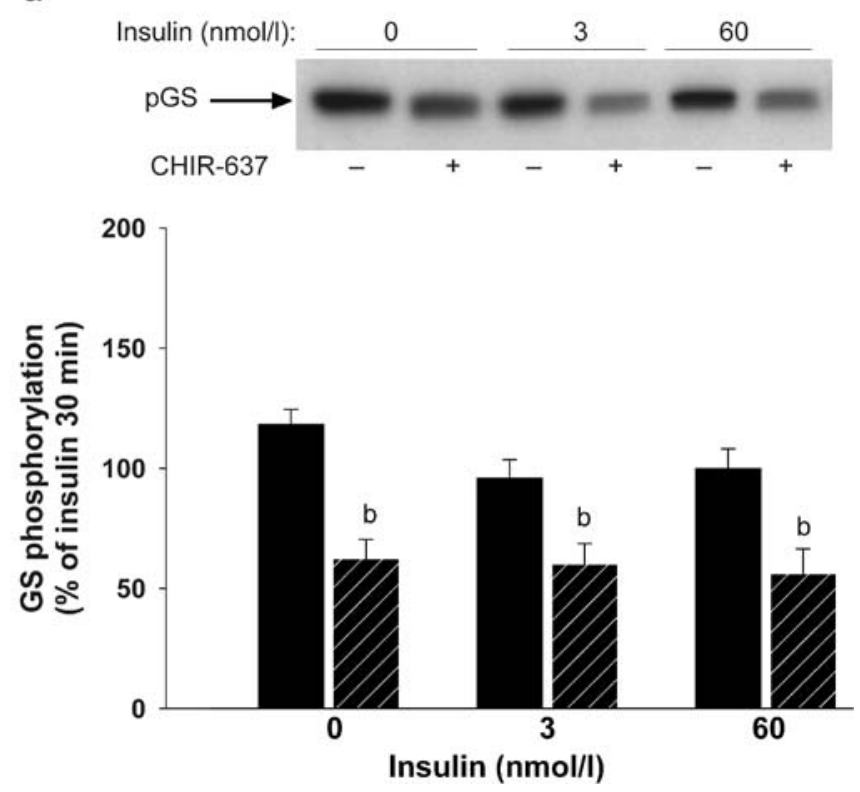

soleus from control rats. b Effects of CHIR-637 on glycogen synthase fractional activity in soleus from dexamethasone-treated rats. $\mathbf{c}$ Effects of CHIR-637 on glycogen synthase phosphorylation in soleus from control rats. d Effects of CHIR-637 on glycogen synthase phosphorylation in soleus from dexamethasone-treated rats Values are mean \pm SEM. $n=7-16$ for each group. ${ }^{a} p<0.02$ vs muscle incubated without insulin from rats exposed to similar treatment; ${ }^{\mathrm{b}} p<0.002$ vs. muscle from control rats incubated with a similar insulin concentration; ${ }^{\mathrm{c}} p<0.02$ vs. muscle incubated with 3 $\mathrm{nmol} / \mathrm{l}$ from rats exposed to similar treatment

GSK-3 $\beta$ or glycogen synthase in skeletal muscles. Expression of GLUT4 has been suggested to determine insulin sensitivity [43], but in agreement with other studies, dexamethasone treatment did not change GLUT4 expression in soleus. In fact, as reported previously [16], glucocorticoid treatment increased GLUT4 expression in the fast-twitch epitrochlearis muscles, probably reflecting the fact that fast-twitch muscles atrophy more than slow-twitch muscles, resulting in higher relative content of membrane proteins. Our data therefore suggest that dexamethasone 
a

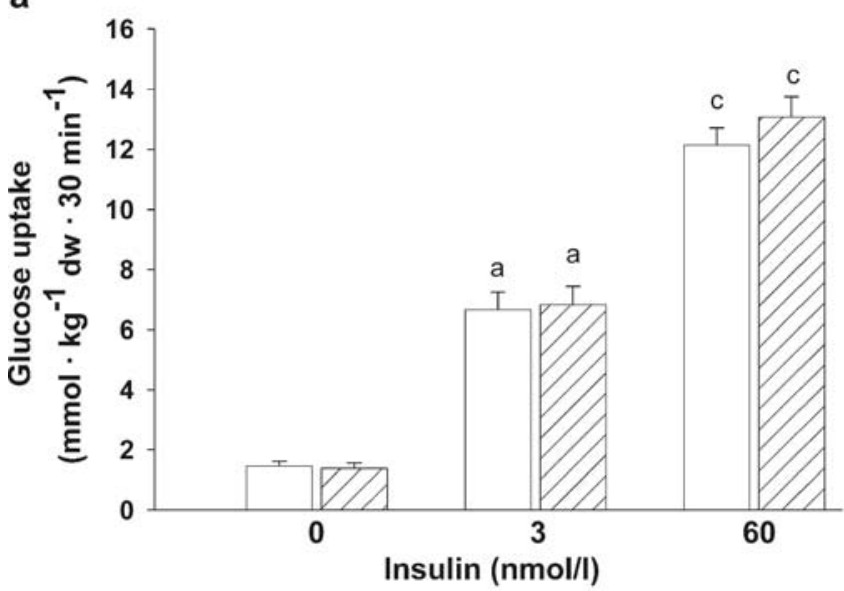

C
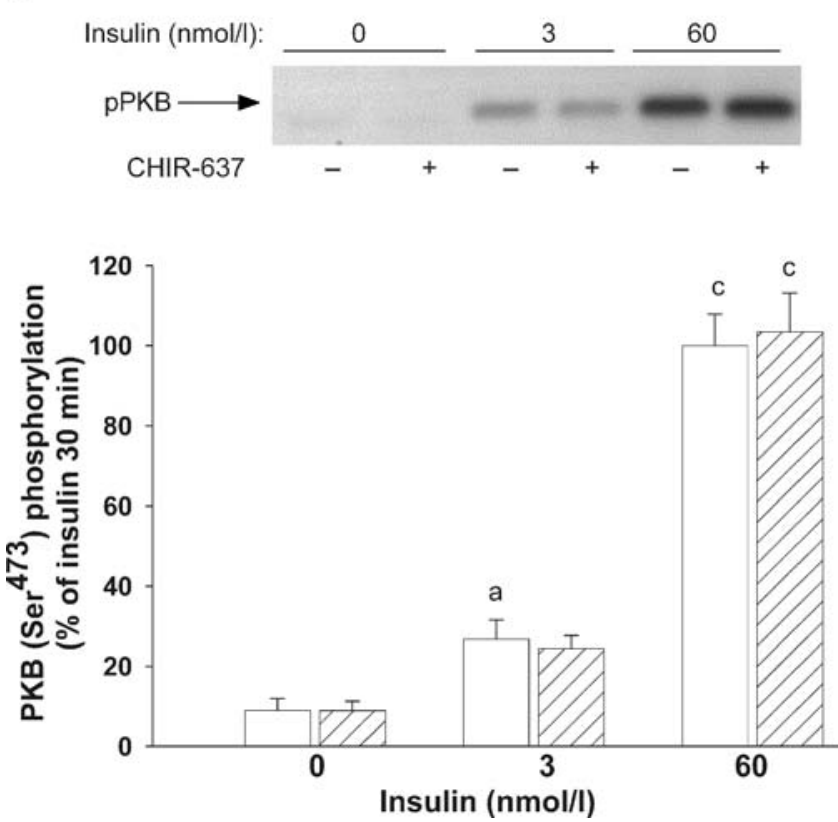

Fig. 8 Effects of CHIR-637 on glucose uptake and PKB phosphorylation. Soleus muscles from control (open bars) and dexamethasone-treated (filled bars) rats were preincubated for $60 \mathrm{~min}$ without or with (hatched bars) $500 \mathrm{nmol} / 1 \mathrm{CHIR}-637$. After this incubation, soleus muscles were incubated for an additional $30 \mathrm{~min}$ in the presence or absence of $500 \mathrm{nmol} / \mathrm{l} \mathrm{CHIR-637}$ and with 0,3 or $60 \mathrm{nmol} / 1$ of insulin. For PKB phosphorylation, soleus muscles incubated for $30 \mathrm{~min}$ with $60 \mathrm{nmol} / 1$ insulin and without CHIR-637 were set at $100 \%$ and other values were calculated as percentages of

induces skeletal muscle insulin resistance by impairing phosphorylation of insulin signalling proteins rather than reducing expression of GLUT4, PKB, GSK-3 or glycogen synthase.

Dexamethasone induces insulin resistance in skeletal muscle without reducing tyrosine phosphorylation of insulin receptor. Insulin-stimulated tyrosine phosphorylation of IRS-1 has also been reported to be normal, whereas dexamethasone treatment reduces IRS-1-associated PI 3 -kinase activity [26]. PI 3-kinase is a heterodimer composed of a regulatory subunit $(\mathrm{p} 85 \alpha)$ and a catalytic sub- b

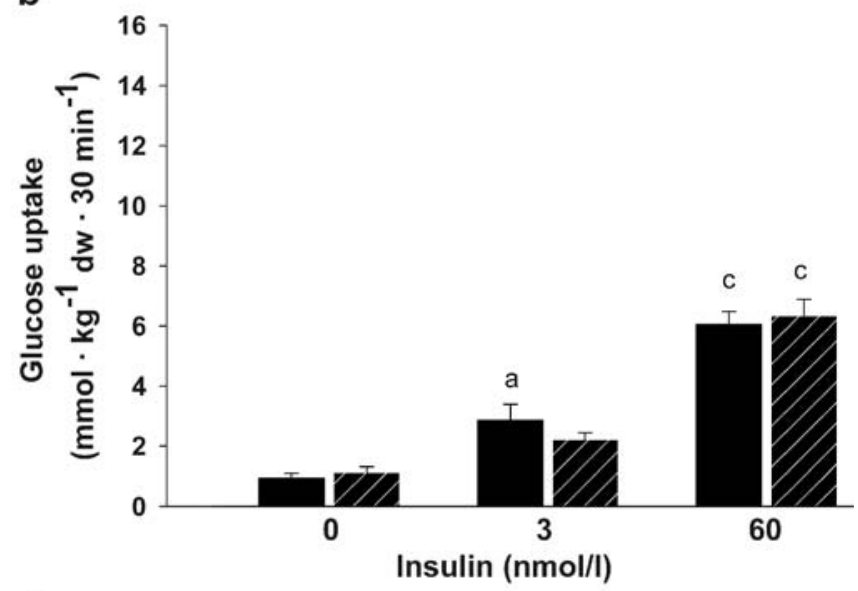

d
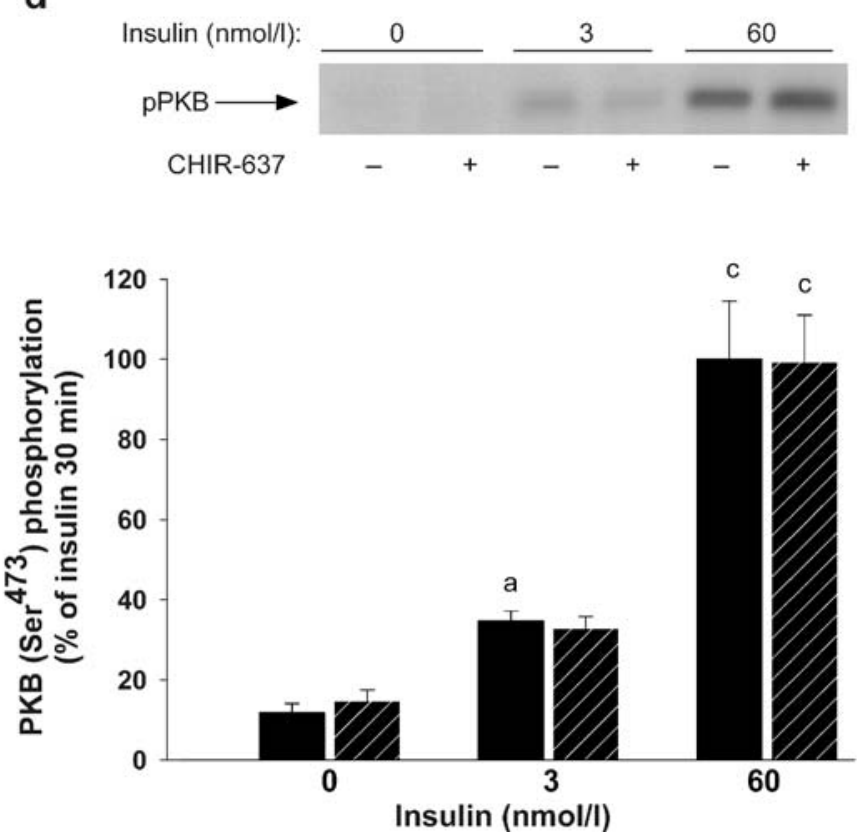

this. a Effects of CHIR-637 on glucose uptake in soleus from control rats. b Effects of CHIR-637 on glucose uptake in soleus from dexamethasone-treated rats. c Effects of CHIR-637 on PKB phosphorylation in soleus from control rats. d Effects of CHIR-637 on PKB phosphorylation in soleus from dexamethasone-treated rats. $d w$ dry weight. Values are mean \pm SEM. $n=7-11$ for each group. ${ }^{a} p<0.05$ vs muscle incubated without insulin from rats exposed to similar treatment; ${ }^{c} p<0.0001$ vs muscle incubated with $3 \mathrm{nmol} / 1$ from rats exposed to similar treatment

unit (p110), and PI 3-kinase is activated when the dimer binds to IRS-1 [9]. It has been hypothesised that $p 85 \alpha$ exists as a free monomer or bound to p110 [44]. Binding of free $\mathrm{p} 85 \alpha$ monomer to IRS-1 does not increase PI 3-kinase activity, but instead competes with binding of the p85 $\alpha$ p110 heterodimer, and consequently impairs PI 3-kinase activation [44]. Support for this hypothesis comes from studies showing that overexpression of $\mathrm{p} 85 \alpha$ reduces insulin signalling in L6 myotubes [45], whereas reduced p $85 \alpha$ expression improves glucose homeostasis and insulin signalling in normal and insulin-resistant mice [46, 47]. 
Our data support the possibility that increased expression of p $85 \alpha$ and competitive inhibition of PI 3-kinase activity may mediate glucocorticoid-induced insulin resistance.

It has been suggested that GSK-3 inhibitors represent a potential therapeutic treatment for type 2 diabetic patients [35]. In the present study, we found that the GSK-3 inhibitor CHIR-637 increased glycogen synthase fractional activity in soleus from normal and dexamethasone-treated rats. This finding is consistent with previous reports showing that GSK-3 inhibitors activate glycogen synthase in lean and ZDF rats [27], and in cultured human skeletal muscle cells from normal and type 2 diabetics [48]. In the present study, CHIR-637 was unable to restore glycogen synthase activation in muscle from dexamethasone-treated rats to that found in muscles from normal rats. While it is difficult to accurately gauge the percentage of GSK-3 which was inhibited in these experiments, the incomplete and slow dephosphorylation of glycogen synthase suggests a lack of protein phosphatase-1 activity in dexamethasonetreated rat muscle. However, the fact that insulin-stimulated glycogen synthase activation was completely blocked in muscles from dexamethasone-treated rats highlights the potential of GSK-3 inhibitors in the treatment of type 2 diabetes mellitus. It is noteworthy that the specific effect of CHIR-637 is supported by reduced glycogen synthase phosphorylation at sites phosphorylated by GSK-3.

Short-term incubation with CHIR-637 did not increase insulin-stimulated glucose uptake or PKB phosphorylation in muscles from dexamethasone-treated rats. Pharmacological inhibition of GSK-3 increases insulin-stimulated glucose uptake in insulin-resistant skeletal muscles from obese ZDF rats but not in muscle from insulin-sensitive lean ZDF rats $[27,28]$. It is not expected that GSK-3 inhibition would have a direct effect on PKB phosphorylation, but GSK-3 has been reported to phosphorylate IRS-1, which reduces activation of PI 3-kinase and PKB [49]. While dexamethasone-induced diabetes in rats may share some of the traits of ZDF rats, insulin-stimulated glucose uptake and PKB phosphorylation were not increased by GSK-3 inhibition in muscles from dexamethasone-treated rats. Inhibition of GSK-3 by CHIR-637 may increase glucose transport in ZDF rats by reducing IRS-1 serine phosphorylation, but there is no evidence that dexamethasone increases serine phosphorylation of IRS-1. In human skeletal muscle cells, however, this class of GSK-3 inhibitor only enhanced insulin-stimulated glucose uptake after prolonged $(>6 \mathrm{~h})$ exposure [48]. It is therefore possible that prolonged incubation of muscle from dexamethasone-treated rats with CHIR-637 might result in increased glucose transport. Further experiments are required to determine whether chronic treatment with GSK-3 inhibitors will increase insulin sensitivity in dexamethasone-induced insulin-resistant muscles.

In conclusion, dexamethasone treatment impairs insulinstimulated glucose uptake and glycogen synthesis in muscle, and our data suggest that insulin resistance may result from increased expression of the $p 85 \alpha$ subunit of PI 3-kinase and reduced PKB phosphorylation. Reduced GSK-3 phosphorylation may contribute to, but not fully explain, the ability of insulin to activate glycogen synthase. Short-term pharmacological inhibition of GSK-3 increased glycogen synthase fractional activity in muscles from dexamethasone-treated rats but did not improve insulinstimulated glucose uptake.

Acknowledgements We thank Jorid Thrane Stuenæs, Ada Ingvaldsend and Astrid Bolling for assistance in some of the experiments, and Einar Eilertsen, Frøydis Kristoffersen and Synøve Bro for animal care. The study was supported by the Research Council of Norway, Novo Nordisk Foundation, and Aktieselskabet Freia Chocolade Fabriks Medisinske Fond.

\section{References}

1. Nosadini R, Del Prato S, Tiengo A et al (1983) Insulin resistance in Cushing's syndrome. J Clin Endocrinol Metab 57:529-536

2. Quddusi S, Browne P, Toivola B et al (1998) Cushing syndrome due to surreptitious glucocorticoid administration. Arch Intern Med 158:294-296

3. Pagano G, Cavallo-Perin P, Cassader M et al (1983) An in vivo and in vitro study of the mechanism of prednisone-induced insulin resistance in healthy subjects. J Clin Invest 72:1814 1820

4. Rosmond R (2003) Stress induced disturbances of the HPA axis: a pathway to Type 2 diabetes? Med Sci Monit 9:RA35RA39

5. Kusunoki M, Cooney GJ, Hara T et al (1995) Amelioration of high-fat feeding-induced insulin resistance in skeletal muscle with the antiglucocorticoid RU486. Diabetes 44:718-720

6. Buckbinder L, Robinson RP (2002) The glucocorticoid receptor: molecular mechanism and new therapeutic opportunities. Curr Drug Targets Inflamm Allergy 1:127-136

7. Gower WR Jr (1993) Mechanism of glucocorticoid action. J Fla Med Assoc 80:697-700

8. Bryant NJ, Govers R, James DE (2002) Regulated transport of the glucose transporter GLUT4. Nat Rev Mol Cell Biol 3:267277

9. Shepherd PR, Withers DJ, Siddle K (1998) Phosphoinositide 3-kinase: the key switch mechanism in insulin signalling. Biochem J 333:471-490

10. Cross DA, Alessi DR, Cohen P et al (1995) Inhibition of glycogen synthase kinase-3 by insulin mediated by protein kinase B. Nature 378:785-789

11. Lawrence JC Jr, Roach PJ (1997) New insights into the role and mechanism of glycogen synthase activation by insulin. Diabetes 46:541-547

12. Jiang ZY, Zhou QL, Coleman KA et al (2003) Insulin signaling through Akt/protein kinase B analyzed by small interfering RNA-mediated gene silencing. Proc Natl Acad Sci U S A 100: 7569-7574

13. Katome T, Obata T, Matsushima R et al (2003) Use of RNA interference-mediated gene silencing and adenoviral overexpression to elucidate the roles of AKT/protein kinase B isoforms in insulin actions. J Biol Chem 278:28312-28323

14. DeFronzo RA, Gunnarsson R, Bjorkman O et al (1985) Effects of insulin on peripheral and splanchnic glucose metabolism in noninsulin-dependent (type II) diabetes mellitus. J Clin Invest 76:149-155

15. Shulman GI, Rothman DL, Jue T et al (1990) Quantitation of muscle glycogen synthesis in normal subjects and subjects with non-insulin-dependent diabetes by $13 \mathrm{C}$ nuclear magnetic resonance spectroscopy. N Engl J Med 322:223-228

16. Haber RS, Weinstein SP (1992) Role of glucose transporters in glucocorticoid-induced insulin resistance. GLUT4 isoform in rat skeletal muscle is not decreased by dexamethasone. Diabetes $41: 728-735$ 
17. Dimitriadis G, Leighton B, Parry-Billings M et al (1997) Effects of glucocorticoid excess on the sensitivity of glucose transport and metabolism to insulin in rat skeletal muscle. Biochem J 321:707-712

18. Leighton B, Challiss RA, Lozeman FJ et al (1987) Effects of dexamethasone treatment on insulin-stimulated rates of glycolysis and glycogen synthesis in isolated incubated skeletal muscles of the rat. Biochem J 246:551-554

19. Coderre L, Srivastava AK, Chiasson JL (1992) Effect of hypercorticism on regulation of skeletal muscle glycogen metabolism by insulin. Am J Physiol Endocrinol Metab 262: E427-E433

20. Björnholm M, Kawano Y, Lehtihet M et al (1997) Insulin receptor substrate-1 phosphorylation and phosphatidylinositol 3-kinase activity in skeletal muscle from NIDDM subjects after in vivo insulin stimulation. Diabetes 46:524-527

21. Goodyear LJ, Giorgino F, Sherman LA et al (1995) Insulin receptor phosphorylation, insulin receptor substrate-1 phosphorylation, and phosphatidylinositol 3-kinase activity are decreased in intact skeletal muscle strips from obese subjects. J Clin Invest 95:2195-2204

22. Krook A, Kawano Y, Song XM et al (1997) Improved glucose tolerance restores insulin-stimulated Akt kinase activity and glucose transport in skeletal muscle from diabetic GotoKakizaki rats. Diabetes 46:2110-2114

23. Krook A, Roth RA, Jiang XJ et al (1998) Insulin-stimulated Akt kinase activity is reduced in skeletal muscle from NIDDM subjects. Diabetes 47:1281-1286

24. Kruszynska YT, Worrall DS, Ofrecio J et al (2002) Fatty acidinduced insulin resistance: decreased muscle PI3K activation but unchanged Akt phosphorylation. J Clin Endocrinol Metab 87:226-234

25. Nadler ST, Stoehr JP, Rabaglia ME et al (2001) Normal Akt/ PKB with reduced PI3K activation in insulin-resistant mice. Am J Physiol Endocrinol Metab 281:E1249-E1254

26. Saad MJ, Folli F, Kahn JA et al (1993) Modulation of insulin receptor, insulin receptor substrate-1, and phosphatidylinositol 3-kinase in liver and muscle of dexamethasone-treated rats. J Clin Invest 92:2065-2072

27. Henriksen EJ, Kinnick TR, Teachey MK et al (2003) Modulation of muscle insulin resistance by selective inhibition of GSK-3 in Zucker diabetic fatty rats. Am J Physiol Endocrinol Metab 284:E892-E900

28. Ring DB, Johnson KW, Henriksen EJ et al (2003) Selective glycogen synthase kinase 3 inhibitors potentiate insulin activation of glucose transport and utilization in vitro and in vivo. Diabetes 52:588-595

29. Cline GW, Johnson K, Regittnig W et al (2002) Effects of a novel glycogen synthase kinase-3 inhibitor on insulin-stimulated glucose metabolism in Zucker diabetic fatty $(f a / f a)$ rats. Diabetes 51:2903-2910

30. Aslesen R, Jensen J (1998) Effects of epinephrine on glucose metabolism in contracting rat skeletal muscles. Am J Physiol Endocrinol Metab 275:E448-E456

31. Lowry OH, Passonneau JV (1972) A flexible system of enzymatic analysis, 1 st edn. Academic, New York

32. Franch J, Aslesen R, Jensen J (1999) Regulation of glycogen synthesis in rat skeletal muscle after glycogen-depleting contractile activity: effects of adrenaline on glycogen synthesis and activation of glycogen synthase and glycogen phosphorylase. Biochem J 344:231-235
33. Whitehead JP, Soos MA, Aslesen R et al (2000) Contraction inhibits insulin-stimulated insulin receptor substrate-1/2-associated phosphoinositide 3-kinase activity, but not protein kinase $\mathrm{B}$ activation or glucose uptake, in rat muscle. Biochem J 349:775-781

34. Laemmli UK (1970) Cleavage of structural proteins during the assembly of the head of bacteriophage T4. Nature 227:680-685

35. Wagman AS, Johnson KW, Bussiere DE (2004) Discovery and development of GSK3 inhibitors for the treatment of type 2 diabetes. Curr Pharm Des 10:1105-1137

36. Danforth W (1965) Glycogen synthetase activity in skeletal muscle. Interconversion of two forms and control of glycogen synthesis. J Biol Chem 240:588-593

37. Coderre L, Srivastava AK, Chiasson JL (1992) Effect of hypercorticism on regulation of skeletal muscle glycogen metabolism by epinephrine. Am J Physiol Endocrinol Metab 262: E434-E439

38. Jensen J, Aslesen R, Jebens E et al (1999) Adrenaline-mediated glycogen phosphorylase activation is enhanced in rat soleus muscle with increased glycogen content. Biochim Biophys Acta 1472:215-221

39. Glass DJ (2003) Signalling pathways that mediate skeletal muscle hypertrophy and atrophy. Nat Cell Biol 5:87-90

40. Garofalo RS, Orena SJ, Rafidi K et al (2003) Severe diabetes, agedependent loss of adipose tissue, and mild growth deficiency in mice lacking Akt2/PKB beta. J Clin Invest 112:197-208

41. Park KS, Ciaraldi TP, Carter L et al (2000) Induction of insulin resistance in human skeletal muscle cells by downregulation of glycogen synthase protein expression. Metabolism 49:962-968

42. Nikoulina SE, Ciaraldi TP, Mudaliar S et al (2000) Potential role of glycogen synthase kinase-3 in skeletal muscle insulin resistance of type 2 diabetes. Diabetes 49:263-271

43. Ivy JL (2004) Muscle insulin resistance amended with exercise training: role of GLUT4 expression. Med Sci Sports Exerc 36:1207-1211

44. Giorgino F, Pedrini MT, Matera L et al (1997) Specific increase in p85alpha expression in response to dexamethasone is associated with inhibition of insulin-like growth factor-I stimulated phosphatidylinositol 3-kinase activity in cultured muscle cells. J Biol Chem 272:7455-7463

45. Ueki K, Algenstaedt P, Mauvais-Jarvis F et al (2000) Positive and negative regulation of phosphoinositide 3-kinase-dependent signaling pathways by three different gene products of the p85alpha regulatory subunit. Mol Cell Biol 20:8035-8046

46. Mauvais-Jarvis F, Ueki K, Fruman DA et al (2002) Reduced expression of the murine p85alpha subunit of phosphoinositide 3-kinase improves insulin signaling and ameliorates diabetes. J Clin Invest 109:141-149

47. Terauchi Y, Tsuji Y, Satoh S et al (1999) Increased insulin sensitivity and hypoglycaemia in mice lacking the p85 alpha subunit of phosphoinositide 3-kinase. Nat Genet 21:230-235

48. Nikoulina SE, Ciaraldi TP, Mudaliar S et al (2002) Inhibition of glycogen synthase kinase 3 improves insulin action and glucose metabolism in human skeletal muscle. Diabetes 51:2190-2198

49. Eldar-Finkelman H, Krebs EG (1997) Phosphorylation of insulin receptor substrate 1 by glycogen synthase kinase $3 \mathrm{im}$ pairs insulin action. Proc Natl Acad Sci U S A 94:9660-9664 